\title{
Carex pallens, a new host species of the smut Anthracoidea irregularis
}

\author{
HARRI HARMAJA
}

\begin{abstract}
HARMAJA, H. 1991: Carex pallens, a new host species of the smut Anthracoidea irregularis - Karstenia 31:29-30.

As Carex pallens (Fristedt) Harmaja (Cyperaceae) has been recognized as a valid species, this sedge becomes the fourth principal Nordic host species known for the ovaricolous smut fungus Anthracoidea irregularis (Liro) Boidol \& Poelt. Carex digitata L. x pallens is reported as a new host of $A$. irregularis. The smut has been found at six Finnish localities on $C$. pallens and at two on $C$. digitata $\times$ pallens. Both smut-host combinations are new to Finland. Anthracoidea irregularis U. Braun \& Hirsch is considered an illegitimate name, being superfluous and a later homonym of $A$. irregularis (Liro) Boidol \& Poelt.
\end{abstract}

Key words: Anthracoidea irregularis, Carex pallens, Finland, nomenclature

Harri Harmaja, Mycology Division, Finnish Museum of Natural History, Unioninkatu 44, SF-00170 Helsinki, Finland

According to Nannfeldt (1979), the smut fungus Anthracoidea irregularis (Liro) Boidol \& Poelt (Ustilaginales) inhabits three principal host species in the Nordic countries: Carex digitata L., C. ornithopoda Willd. and C. pediformis C.A. Meyer s. lato (Cyperaceae). The hosts are closely related and belong to sect. Digitatae. From the Nordic countries the smut is also known on the hybrid $C$. digitata $\times$ ornithopoda and on the accidental host $C$. tomentosa $\mathrm{L}$. (sect. Montanae; Nannfeldt 1979). One additional host, $C$. halleriana Asso (often included in the section Hallerianae), occurs in central Europe. The main area of the smut comprises northern, central and eastern Europe; it is also known on $C$. pediformis s. lato from Japan (Nannfeldt 1979) and Mongolia (Vánky, exsiccate).

Nannfeldt (1979) reported that besides occurring on $C$. digitata var. digitata, $A$. irregularis is found on $C$. digitata var. pallens Fristedt. Since the latter variety has been accorded specific rank, as $C$. pallens (Fristedt) Harmaja (Harmaja 1986, 1990), it becomes the fourth principal host species of A. irregularis in the Nordic countries.

In two Finnish localities (see below), I have found A. irregularis on C. digitata $\times$ pallens, which is a new host of the smut. This hybrid was reported as new by Harmaja (1986) and was later treated more comprehensively in Harmaja (1990).
A. irregularis was found by me on $C$. pallens in five Finnish localities, and a search through the $\mathrm{Ca}$ rex and Anthracoidea collections of $\mathrm{H}$ revealed one more locality, all from the province Etelä-Häme; the specimens are listed below. In all but one case the infection is extremely sparse: only one or two infected perigynia were found. $C$. digitata, growing near by, was mostly infected, too, the infection usually being likewise very scanty. There are numerous collections of A. irregularis on the latter species from EteläHäme, and also some on C. pediformis subsp. rhizodes (Blytt) H. Lindb.

Both smut-host combinations, $A$. irregularis/C. pallens and A. irregularis/C. digitata $\times$ pallens, are new to Finland. The former combination has been reported earlier from one locality in northern Sweden, prov. Ångermanland (Nannfeldt 1979).

Controversial opinions have been presented on the first valid publication of Anthracoidea irregularis. Nannfeldt (1979) and Vánky (1985) claim that the basionym is Cintractia irregularis Liro 1934, while Braun \& Hirsch (1978), Stafleu \& Cowan (1981) and Braun (1982) claim that this name was effectively published only in 1935, and is thus illegitimate because it was described in German, and Latin descriptions became obligatory from 1 January 1935. The decision is not easy. Liro indicates on the list of con- 
tents attached on the cover of his bound exsicata Mycotheca fennica Fasc. 1, and also in the bound book of exsiccata labels (Liro 1935: 2) that labels Nos. 1-100 were printed on 20.XII.1934. This information is probably reliable, but it does not indicate when the labels were made available, which is more important that the printing time. In the absence of definite data, I propose that Art. 30.1. of the 'Code' is followed ("in the absence of proof establishing some other date, the one appearing in the printed matter must be accepted as correct"). We may assume that, in spite of the Christmas season, the labels arrived in 1934 at the Department of Plant Pathology, University of Helsinki, where Professor Liro worked, and were immediately cut out and pasted on the exsiccate sets. This fulfils the requirement of effective publication, even if no finished, bound sets of the exsiccata (Liro 1934) were sent out that year. Indeed, it seems that the bound book of exsiccata labels (Liro 1935) was not published until 1935, later than the loose labels. The loose labels were thus presumably available before the book of labels, but, according to the 'Code', printed protologues on exsiccata labels constituted effective publication before 1953.

\section{Specimens examined}

\section{Anthracoidea irregularis/Carex pallens}

Finland. Etelä-Häme. Asikkala: Vääksy, VII.1946 Kalela (H). Koski: Huljala, Kukkolanharju, Grid 27ㄹ: 6767:403, 3.VI.1984 Harmaja (H). Lammi: Ylänăinen, Jyrkänmäki, alt. 170 m, Grid $27^{\circ} \mathrm{E}$ : 6774:394, 26.V.1986 Harmaja (H); Halila, Revasvuori, alt. ca. $150 \mathrm{~m}$, Grid $27^{\circ} \mathrm{E}: 6774: 396,30 . \mathrm{V} .1986$ Harmaja (H); Kaitala, WNW of Outsilta, infection fairly abundant, Grid $27^{\circ} \mathrm{E}$ : 6774:390, 24.V.1990 Harmaja (H). Sysmă: Karilanmaa, Grid $27^{\circ} \mathrm{E}: 6807: 427,24$. VI. 1990 Harmaja $(\mathrm{H})$.

\section{Anthracoidea irregularis/Carex digitata $\times$ pallens}

Finland. Etelä-Häme. Lammi: Lampelto, SE of Revasvuori, alt. 130 m, Grid $27^{\circ} E$ : 6774:396, 30.V.1986 Harmaja (H). Sysmä, Karilanmaa, Grid $27^{\circ}$ E: 6807:427, 24.VI.1990 Harmaja (H).

Acknowledgements. I am indebted to Prof. Teuvo Ahti for improvements of the paper and to Ms. Anna A. Damström, M.A., for revising the English of the manuscript.

\section{References}

Braun, U. 1982: Anthracoidea pseudirregularis spec. nov. Boletus 6:52-53.

Braun, U. \& Hirsch, G. 1978: Übersicht über die europäischen Arten der Gattung Anthracoidea Bref. (Ustilaginales). - Feddes Rep. 89:43-60.

Harmaja, H. 1986: Carex pallens, an overlooked Fennoscandian species. - Ann. Bot. Fennici 23:147-151.

Harmaja, H. 1990: On the taxonomy and chorology of Carex pallens. - Ann. Bot. Fennici 27:79-83.

Liro, J.I. 1934: Mycotheca Fennica. Fasc. 1, No. 1-50. Helsinki.

Liro, J.I. 1935 ('1934'): Mycotheca Fennica. Die Etiketten. N:o 1-300. - 97 pp. Inst. Phytopatol. Univ. Helsinkiensis.

Nannfeldt, J.A. 1979: Anthracoidea (Ustilaginales) on Nordic Cyperaceae-Caricoideae, a concluding synopsis. - Symb. Bot. Upsalienses 22(3): 1-41.

Stafleu, F.A. \& Cowan, R.S. 1981: Taxonomic literature. Vol. III: Lh-O. - Regnum Veget. 105:1-980.

Vánky, K. 1985: Carpathian Ustilaginales. - Symb. Bot. Upsalienses 24(2):1-309.

Received on 24 January 1990 